\title{
Production of Biomass of Lactic Acid Bacteria Using Optimized Solid Substrate in Self-Technique
}

\author{
Akshaykumar*, H. Manjunatha and B. Ramachandra \\ Department of Dairy Microbiology, Dairy Science College, Hebbal, Bengaluru, India \\ *Corresponding author
}

\section{A B S T R A C T}

\begin{tabular}{|c|c|}
\hline Keywords & biomass of lactic acid bacteria using various dhals such as raw bengal gram dhal, roasted \\
\hline $\begin{array}{l}\text { Black gram dhal, } \\
\text { Supplements, Lactic } \\
\text { acid bacteria, } \\
\text { Biomass. }\end{array}$ & $\begin{array}{l}\text { dhal, red gram dhal, soya bean dhals for growing Lactic Acid Bacteria using the solid state } \\
\text { fermentation technique after screening for bacterial spores. The screened black gram dhal } \\
\text { was selected which found to have lowest spore count of } 1.52 \log _{10} \text { cfu/g then were } \\
\text { exposed to hot air oven at } 100^{\circ} \mathrm{C} \text { for } 1 \mathrm{~h} \text { and sterilization at } 121^{\circ} \mathrm{C} \text { for } 30 \mathrm{~min} \text { for complete }\end{array}$ \\
\hline Article Info & $\begin{array}{l}\text { destruction of spores. The black gram dhal was added with various supplements each of } \\
\text { skim milk powder, ash guard juice, carrot juice and tomato juice as sources of growth }\end{array}$ \\
\hline $\begin{array}{l}\text { Accepted: } \\
\text { 21 October } 2017 \\
\text { Available Online: } \\
10 \text { December } 2017\end{array}$ & $\begin{array}{l}\text { factors at the rate of } 0.5,1,1.5 \text { and } 2 \% \text {. The cultures selected for biomass production were } \\
\text { dhai culture, yoghurt culture and acidophilus cultures added at } 1 \% \text { level of inoculum. The } \\
\text { optimum growth was obtained when supplements were added each at } 1 \% \text { concentration } \\
\text { with maximum viable counts for dahi culture was } 8.41 \log _{10} \mathrm{cfu} / \mathrm{g} \text { while yoghurt culture of } \\
8.98 \log _{10} \mathrm{cfu} / \mathrm{g} \text { and acidophilus culture of } 9.47 \log _{10} \mathrm{cfu} / \mathrm{g} \text {. }\end{array}$ \\
\hline
\end{tabular}

\section{Introduction}

Food is an inevitable human need for optimum physical and mental functioning which collectively termed as health. Overall health, depends on the nutritional quality, safety and balance of the food consumed. Spoilage of foods mainly is due to physical damage, chemical reaction or through biological agents like microorganisms including bacteria, fungi and also may be worms as well as insects. Based on the water activity, foods are classified into perishable, semi perishable and non-perishable ones.

Milk is considered as universal food, as it has most of the nutrients required for a human being as well as a good medium for the growth of microorganisms which enter from various sources. Fermentation of milk preserves its nutrients for long time and fermentation is made possible by inoculating the heat treated milk with lactic acid bacteria. Fermented milk products have their own importance in the human diet by extending potential therapeutic benefits to the consumers. People have the concept of using fermented milk products as they are safe for consumption due to fermentation end products of the lactic cultures.

Based on the substrate, fermentation may be submerged fermentation $(\mathrm{SmF})$ in liquid media or Solid State Fermentation (SSF) on 
solid substrates like nutritive (dhal, rice) or inert substrates (paddy husk). Solid state fermentation technique has been widely used in preparation of fermented foods, enzymes, organic acids, polysaccharides, biomass of lactic acid bacteria, colours and flavours that involve the controlled growth of microorganisms on solid substrates in the absence of free moisture, so as to obtain large number of viable cells in concentrated form (Bhargav et al., 2008).

Biomass production of lactic acid bacteria is important to serve as active inoculum to produce fermented milk products. Lactic acid bacteria can be grown in milk or whey as liquid media or may be on solid substrate like dhal or bran.

Edible substrates such as dhals are used as solid substrates to grow the cells to maximum level up to $10^{10}$ cells per gram due to more surface area for growth. In conventional liquid culture, the cell growth is limited maximum up to $10^{8}$ cells per millilitre, due to acidic pool during the growth of cells in the presence of free moisture (Koyani and Rajput, 2015).

Lactic acid bacteria (LAB) are a group of microaerophilic, Gram positive, non-spore forming bacteria that ferment lactose to produce primarily lactic acid. LAB include a variety of industrially important genera such as Lactococcus, Streptococcus, Leuconostoc, Pediococcus and Lactobacillus. Probiotics like Lactobacillus acidophilus, Lactobacillus rhamnosus and Bifidobacterium bifidum are live microorganisms thought to be beneficial to the host organism when ingested through food.

Hence, in this study attempt has been made to grow lactic cultures on suitable edible solid substrate with proper supplementation for the biomass production.

\section{Materials and Methods}

\section{Lactic acid bacterial cultures}

The dahi culture consisting of Lactococcus lactiss sp. lactis and Lactococcus lactiss sp. lactis bv. diacetylactis, yoghurt culture that included Streptococcus thermophiles and Lactobacillus delbrueckiis sp. Bulgaricus and Lactobacillus acidophilus as probiotic culture, which had been maintained in sterile Yeast glucose chalk litmus milk (YGCLM) in the department of Dairy Microbiology, Dairy science college, KVAFSU, Hebbal, Bengaluru-24 were used in this study.

\section{Collection and Screening of various dhals for aerobic spore counts}

Dhals of 8 various types, commonly available in local market of Bengaluru such as raw bengal gram dhal, roasted bengal gram dhal, black gram dhal, green gram dhal, hyacinth dhal (avaraebele), masoor dhal, red gram dhal, soya bean dhal were purchased, cleaned to remove stones and unwanted plant materials and stored in a self-sealing polythene pouches.

To determine the extent of spores present in dhals, they were subjected to aerobic spore counts by plating method as per Harrigan (1998).

\section{Various sporicidal treatments to black gram dhal to use as solid substrate}

Various treatments like dry heat treatment such as dry frying (5 min), exposure to microwave $(1 \mathrm{~min})$ and exposure to $100^{\circ} \mathrm{C}$ for $1 \mathrm{~h}$ in hot air oven and wet heat treatments like hydration of dhal for $30 \mathrm{~min}, 12 \mathrm{~h}$ and 24 $\mathrm{h}, 0.01 \%$ and $0.05 \%$ treatment with hydrogen peroxide and tyndallization (steaming for 3 successive days) were given to dhal to reduce aerobic spore count and after treatment 
analysed the treated dhal for aerobic spore count as mentioned in Harrigan (1998).

\section{Supplementation for treated black gram dhal for the growth of lactic cultures}

Best sporicidal treatment to completely destroy aerobic spore was selected and then supplemented with skim milk powder, ash guard juice, carrot juice and tomato juice.

\section{Preparation of ash guard juice, carrot juice and tomato juice}

Ash guard, carrot and tomato were obtained freshly from local market. The edible portions were obtained, washed with potable water, grated, steamed for $15 \mathrm{~min}$ and mashed in clean, dry, mixer. The obtained puree was filtered through muslin cloth. After filtration the juices of ash guard, carrot and tomato were collected separately in a sterile conical flask.

\section{Final supplementation to black gram dhal}

The aerobic spore free black gram dhal was supplemented with each of SMP, ash guard juice, carrot juice and tomato juice at $0.5,1$, 1.5 and $2 \%$ level. The moisture maintained was 1:0.8 level, including volume of water in juices.

\section{Statistical analysis}

The data was analyzed using $\mathrm{R}$ software [R. version 3.1.3 (2015-3-09), copyright (C) 2015, $\mathrm{R}$ foundation] for statistical computing both one way and two way Completely Randomed Design (CRD) which is the most appropriate for the study. Data on the response variables were collected for three replications for each of these treatments. ANOVA tables were prepared to analyse the data and where the $\mathrm{F}$ value was significant the critical difference was calculated and used to identify where significant differences existed and was indicated in the table use superscripts. The formula for the critical difference (CD) is

$\mathrm{CD}=\frac{\sqrt{2 \times \mathrm{MSS}(\mathrm{E})}}{\mathrm{R}} \mathrm{t} \alpha$

Where,

MSS $(E)=$ Mean Sum of squares of the error $\mathrm{r}=$ number of replications

t $\alpha=$ table $t$ value of the $\alpha$ level of significance

\section{Results and Discussion}

Screening of various dhals for aerobic spore count

Various locally available dhals were used as solid substrates for fermentation using lactic cultures as they provide more surface area for the growth of lactic acid bacteria and also a good source of proteins, calcium and iron. They imbibe water during soaking and also do not sag as well as agglomerate maintaining their grainy texture. Previous studies carried out in the same laboratory, also had shown use of dhal as good solid substrate for growth of lactic cultures. These dhals contain low moisture and hence major contaminant being aerobic spores. The aerobic spores of bacteria which enter through soil and air are most resistant for heat treatments and their initial load also has significant effect on the survivability. Preliminary requirement was to screen dhals for their aerobic spore counts.

The dhal samples of 8 numbers were obtained from local market, Bengaluru such as raw bengal gram dhal, roasted bengal gram dhal, black gram dhal, green gram dhal, hyacinth dhal, masoor dhal, red gram dhal and soya bean dhal, cleaned and stored in polythene pouches. Various dhals were subjected to enumeration of aerobic spore count by subjecting to heat treatment at $80^{\circ} \mathrm{C}$ for $10 \mathrm{~min}$ 
with help of $2 \%$ Nutrient agar medium. The aerobic spore counts was less in black gram dhal $\left(1.52 \log _{10} \mathrm{cfu} / \mathrm{g}\right)$ followed by masoor dhal (2.78 $\left.\log _{10} \mathrm{cfu} / \mathrm{g}\right)$, green gram dhal (2.98 $\left.\log _{10} \mathrm{cfu} / \mathrm{g}\right)$, raw bengal gram dhal (3.47 $\log _{10}$ $\mathrm{cfu} / \mathrm{g})$, roasted Bengal gram dhal (3.54 $\log _{10}$ cfu/g), hyacinath dhal (3.69 $\log _{10} \mathrm{cfu} / \mathrm{g}$ ), red gram dhal (4.15 $\left.\log _{10} \mathrm{cfu} / \mathrm{g}\right)$ and soya bean dhal $\left(5.05 \quad \log _{10} \mathrm{cfu} / \mathrm{g}\right)$. Predominance of aerobic spore counts was less in case of black gram dhal compared to other dhals may be due to unknown antimicrobial agent. Hence black gram dhal was selected as an edible solid substrate in the further studies (Table 1 and Fig. 1).

\section{Various sporicidal treatments to black gram dhal to use as solid substrate}

In order to completely destroy the spores, various methods were adopted in the present study. Black gram dhal was subjected for dry and wet treatments and finally autoclaved at $121^{\circ} \mathrm{C}$ for $30 \mathrm{~min}$ to destroy the aerobic spores completely.

Dry treatments given for black gram dhal included dry frying (5 $\mathrm{min})$, exposure to microwave $(1 \mathrm{~min})$, exposure to $100^{\circ} \mathrm{C}$ for 30 min and exposure to $100^{\circ} \mathrm{C}$ for $1 \mathrm{~h}$. These treatments reduced aerobic spore in the range 0 to $2.59 \log _{10} \mathrm{cfu} / \mathrm{g}$ in black gram dhal.

Among wet heat treatments for black gram dhal like hydration, hydrogen peroxide treatment and tyndallisation, the viable aerobic spore count was between 1.30 and $3.11 \log _{10} \mathrm{cfu} / \mathrm{g}$ (Table 2 and Fig. 2). Several treatments like dry frying, hydration increased the spore counts, indicating the ability to survive and resist the final heating at $121^{\circ} \mathrm{C}$ for $30 \mathrm{~min}$. Even steaming for 3 successive days termed tyndallisation as well as the addition of hydrogen peroxide did not show complete destruction of spores. Exposure of dhal in hot air oven at $100^{\circ} \mathrm{C}$ for $1 \mathrm{~h}$ and then sterilization at $121^{\circ} \mathrm{C}$ for $30 \mathrm{~min}$ resulted in complete destruction of aerobic spore. Hot air might have sensitized the spores and latter wet heat at $121^{\circ} \mathrm{C}$ for $30 \mathrm{~min}$, helped to kill the remaining spores or vegetative cells. Hence, the same method was followed in further study.

Literature regarding spoircidal treatment to dhal is very scanty. Nakauma et al., (2004) applied radiations combined with a traditional heat approach $\left(85-95^{\circ} \mathrm{C}\right)$, to inactivate Alicyclobacillus acidoterrestris spores in dextrin powder by $1.5 \log$ at $1.0 \mathrm{kGy} / \mathrm{y}$ for 1 h. Bevilacqua et al., (2008) also reported reduction of Alicyclobacillus acidoterrestris in asparagus cream, containing olive oil from $2 \log$ at $900-2450 \mathrm{MHz}$ for 5-7 min.

Somavat et al., (2012) had found ohmic treatments at frequencies of $60 \mathrm{~Hz}$ and 10 $\mathrm{kHz}$ showed a general trend of accelerated spore inactivation compared to conventional heating at $121^{\circ} \mathrm{C}$ to $130^{\circ} \mathrm{C}$. They hypothesized that vibration of polar dipicolinic acid molecules and spore proteins to electric fields at high temperature conditions may result in the accelerated inactivation.

\section{Effect of different levels of supplementation to black gram dhal on the growth of lactic cultures}

In order to get maximum growth, black gram dhal was added with various supplements each of skim milk powder (milk source), ash guard juice (dietary fiber), carrot juice (pantathine) and tomato juice (manganese sulphate) as sources of growth factors or prebiotic for lactic and probiotic cultures at the rate of $0.5,1,1.5$ and $2 \%$. Out of 0.5 to $2 \%$ supplementation to black gram dhal for enhanced growth of dahi, yoghurt and acidophilus, $0.5 \%$ showed lower viable counts of $8.05,8.39$ and $8.15 \log _{10} \mathrm{cfu} / \mathrm{g}$ respectively (Fig. 3). 
Table.1 Screening of various dhals for aerobic spore count

\begin{tabular}{|c|c|c|}
\hline Name of dhal & Botanical nomenclature & $\begin{array}{l}\text { Aerobic spore count } \\
\quad\left(\log _{10} \mathrm{cfu} / \mathrm{g}\right)\end{array}$ \\
\hline \multicolumn{3}{|l|}{ Bengal gram dhal } \\
\hline a) Raw & \multirow{2}{*}{ Cicer aritinum $\mathrm{L}$} & $3.47^{\mathrm{a}}$ \\
\hline b) Roasted & & $3.54^{\mathrm{a}}$ \\
\hline Black gram dhal & Vigna mungo & $1.52^{\mathrm{b}}$ \\
\hline Green gram dhal & Vigna radiata & $2.98^{\mathrm{a}}$ \\
\hline Hyacinath dhal (Avaraebele) & Lablab purpureus & $3.69^{\mathrm{a}}$ \\
\hline Masoor dhal & Lens culinaris & $2.78^{\mathrm{a}}$ \\
\hline Red gram dhal & Cajanus cajan & $4.15^{\mathrm{a}}$ \\
\hline Soya bean dhal & Glycine max & $5.05^{\mathrm{a}}$ \\
\hline \multicolumn{2}{|c|}{$\mathrm{CD}(\mathrm{p} \leq 0.05)$} & 1.73 \\
\hline
\end{tabular}

Note

The results were average of three trials.

Same superscript indicates non-significance while different, indicates statistically significant difference at $\mathrm{p} \leq 0.05$. First dilution heated to $80^{\circ} \mathrm{C}$ for $10 \mathrm{~min}$ for selection of aerobic spores.

Sterile $2 \%$ Nutrient agar was used for plating with incubation at $37^{\circ} \mathrm{C}$ for $24-48 \mathrm{~h}$.

Table.2 Various sporicidal treatments to black gram dhal to use as solid substrate

\begin{tabular}{|c|c|}
\hline Type of treatment & $\begin{array}{c}\text { Surviving aerobic spores } \\
\left(\log _{10} \mathrm{cfu} / \mathrm{g}\right)\end{array}$ \\
\hline \multicolumn{2}{|l|}{ I Dry treatments } \\
\hline a) Dry frying (5 min) & $2.59^{\mathrm{a}}$ \\
\hline b) Exposure to microwave (1 $\mathrm{min})$ & $1.84^{\mathrm{a}}$ \\
\hline c) Exposure to $100^{\circ} \mathrm{C}$ for $30 \mathrm{~min}$ & $1.45^{\mathrm{b}}$ \\
\hline d) Exposure to $100^{\circ} \mathrm{C}$ for $1 \mathrm{~h}$ & $0.00^{\mathrm{b}}$ \\
\hline \multicolumn{2}{|l|}{ II Wet treatments } \\
\hline \multicolumn{2}{|l|}{ a) Hydration } \\
\hline i. 30 min. & $2.51^{\mathrm{a}}$ \\
\hline ii. $12 \mathrm{~h}$. & $3.11^{\mathrm{a}}$ \\
\hline iii. $24 \mathrm{~h}$. & $1.30^{\mathrm{b}}$ \\
\hline \multicolumn{2}{|l|}{ b) Hydrogen peroxide after hydration } \\
\hline i. $0.01 \%$ & $1.95^{\mathrm{a}}$ \\
\hline ii. $0.05 \%$ & $1.69^{\mathrm{a}}$ \\
\hline $\begin{array}{l}\text { c) Tyndallisation after hydration } \\
\text { (steamed for } 3 \text { successive days) }\end{array}$ & $1.31^{\mathrm{b}}$ \\
\hline $\mathrm{CD}(\mathrm{p} \leq \mathbf{0 . 0 5})$ & 1.05 \\
\hline
\end{tabular}

Note

I Dry treatments

b) Exposure to microwave (1 min)

d) Exposure to $100^{\circ} \mathrm{C}$ for $1 \mathrm{~h}$ 
Table.3 Effect of different levels of supplementation to black gram dhal on the growth of lactic cultures

\begin{tabular}{|c|c|c|c|c|c|c|}
\hline \multirow[t]{3}{*}{ Culture } & \multirow[t]{3}{*}{ Parameter } & \multicolumn{4}{|c|}{$\begin{array}{c}\text { Percentage of supplements added to black gram dhal each } \\
\text { (W/V) } \\
\text { Skim milk powder + Ash guard juice + Carrot juice + Tomato } \\
\text { juice }\end{array}$} & \multirow[t]{3}{*}{$\begin{array}{l}\mathrm{CD}(\mathrm{p} \leq \\
0.05)\end{array}$} \\
\hline & & $\mathbf{0 . 5 \%}$ & $1 \%$ & $1.5 \%$ & $2 \%$ & \\
\hline & & \multicolumn{4}{|c|}{ Viable counts $\left(\log _{10} \mathrm{cfu} / \mathrm{g}\right)$} & \\
\hline \multirow[t]{2}{*}{ Dahi } & $\begin{array}{l}\text { Control } \\
\text { supplements) }\end{array}$ & $6.24^{\mathrm{a}}$ & $6.24^{\mathrm{a}}$ & $6.24^{\mathrm{a}}$ & $6.24^{\mathrm{a}}$ & 0.02 \\
\hline & With supplements & $8.05^{\mathrm{a}}$ & $8.41^{\mathrm{a}}$ & $7.75^{\mathrm{a}}$ & $7.29^{\mathrm{a}}$ & 1.13 \\
\hline \multirow{2}{*}{ Yoghurt } & Control & $6.53^{\mathrm{a}}$ & $6.53^{\mathrm{a}}$ & $6.53^{\mathrm{a}}$ & $6.53^{\mathrm{a}}$ & 0.02 \\
\hline & With supplements & $8.39^{\mathrm{a}}$ & $8.98^{\mathrm{a}}$ & $7.80^{\mathrm{a}}$ & $7.30^{\mathrm{a}}$ & 1.96 \\
\hline \multirow{2}{*}{$\begin{array}{l}\text { Lactobacillus } \\
\text { acidophilus }\end{array}$} & Control & $6.00^{\mathrm{a}}$ & $6.00^{\mathrm{a}}$ & $6.00^{\mathrm{a}}$ & $6.00^{\mathrm{a}}$ & 0.02 \\
\hline & With supplements & $8.15^{\mathrm{a}}$ & $9.47^{\mathrm{a}}$ & $7.98^{\mathrm{a}}$ & $7.79^{\mathrm{a}}$ & 1.70 \\
\hline
\end{tabular}

Note:

The results were average of three trials.

Same superscript shows non-significance while different indicates statistically significant difference at $p \leq 0.05$.

Moisture 1:0.8 were added to black gram dhal (Moisture of 0.8 includes volume of incorporated juices)

The inoculum was added at $1 \%$ with incubation of $30^{\circ} \mathrm{C}$ for dahi and $37^{\circ} \mathrm{C}$ for both yoghurt and acidophilus culture 
Fig.1 Screening of various dhals for aerobic spore count

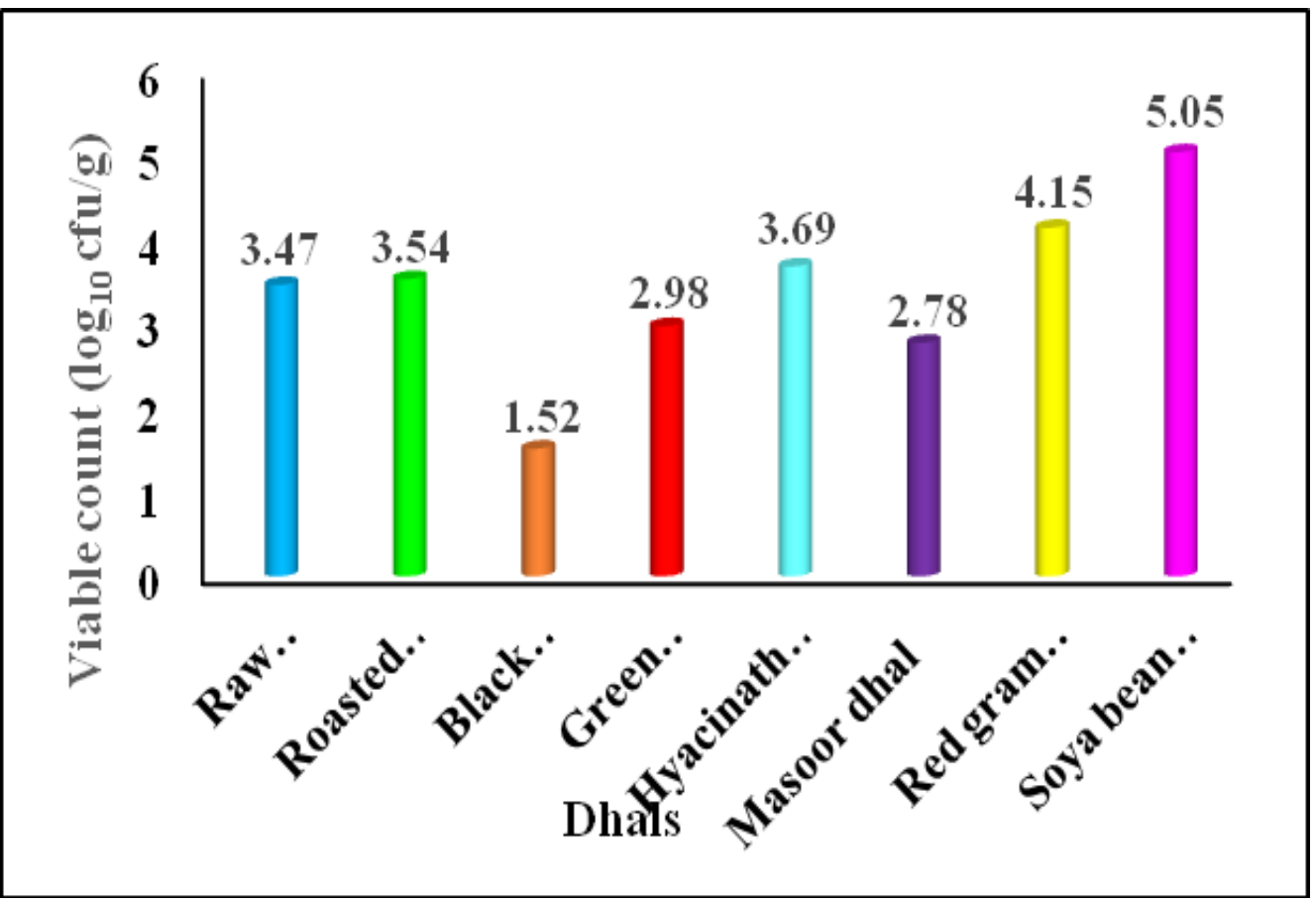

Fig.2 Various sporicidal treatment to black gram dhal to use as solid substrate.

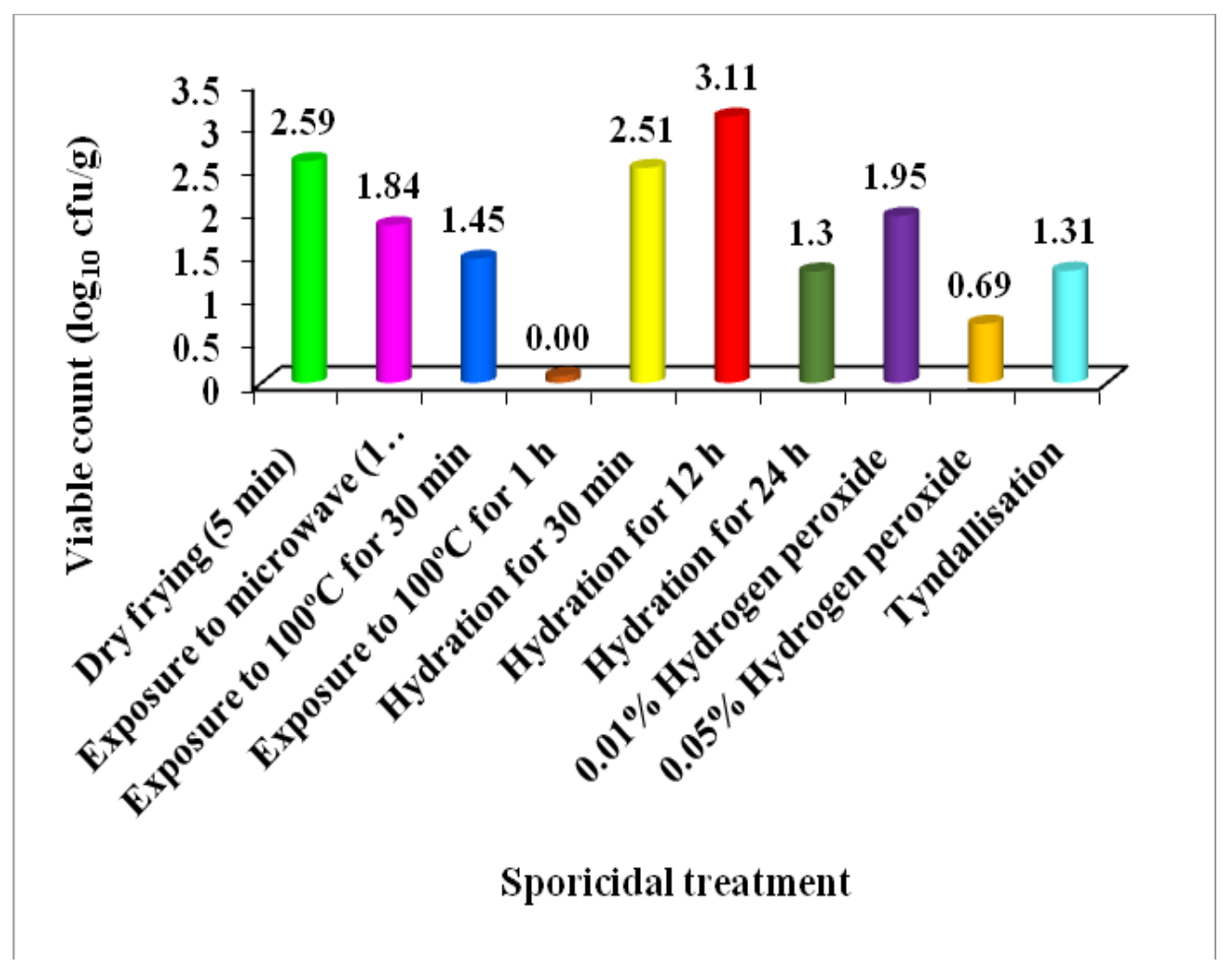


Fig.3 Effect of different levels of supplementation to black gram dhal on the growth of lactic cultures

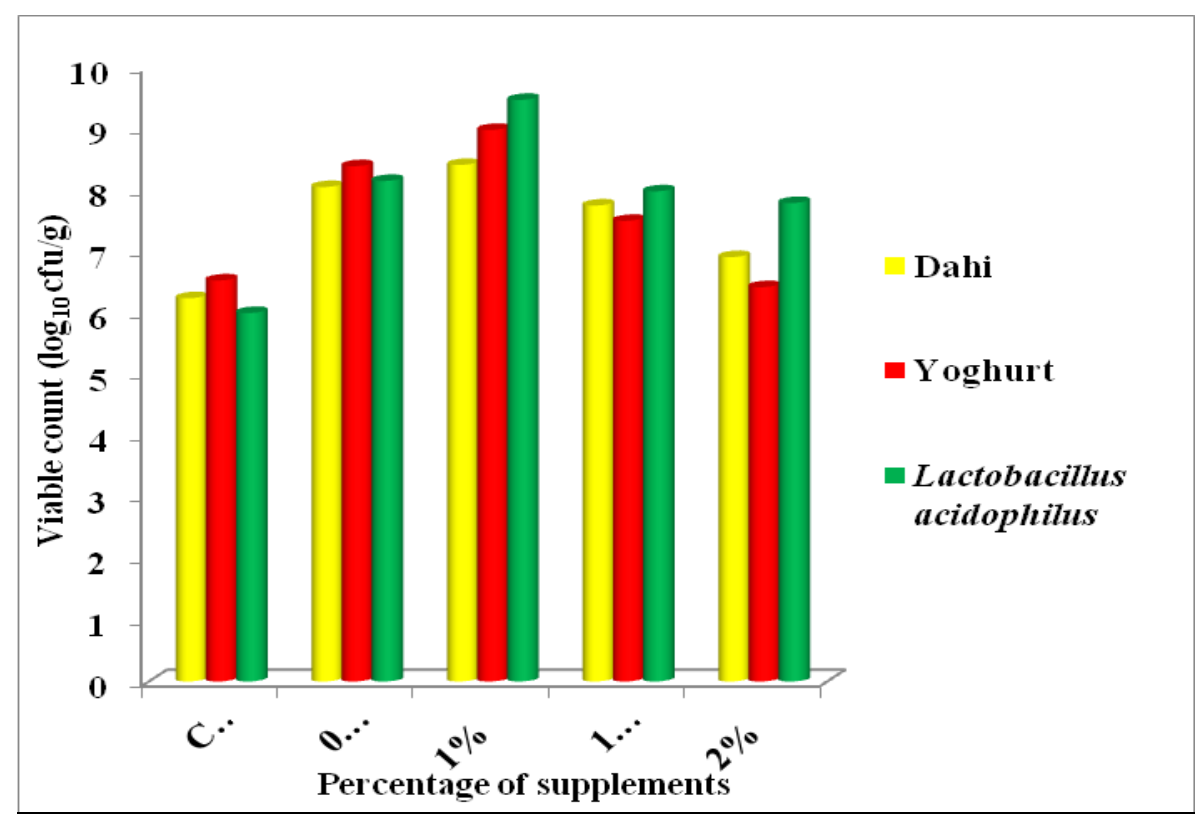

The trend was almost similar at 1.5 and $2 \%$ supplementation, where in the viable counts obtained on black gram dhal for dahi, yoghurt and acidophilus were lower accounting for 7.75, 7.80, $7.98 \log _{10} \mathrm{cfu} / \mathrm{g}$ and 7.20, 7.30, $7.79 \log _{10} \quad \mathrm{cfu} / \mathrm{g}$ respectively. Optimum growth was obtained when supplements were added each at $1 \%$ concentration with $\log$ counts of 8.41 for dahi, 8.98 for yoghurt and $9.47 \log _{10} \mathrm{cfu} / \mathrm{g}$ for acidophilus cultures (Table 3). Supplementation of $0.5 \%$ may be lesser for the growth of lactic cultures, higher per cent reduced counts which may be attributed to more lactic acid production that affected viability of lactic culture. Biomass increase among lactic cultures significantly varied with respect to per cent of incorporation of each supplement of SMP, ash guard juice, carrot juice and tomato juice at $\mathrm{p} \leq 0.05$.

On par with the present study, Vanisri (1995) supplemented black gram dhal having (1:1) moisture, with $10 \%$ skim milk powder that supported the growth of Lactobacillus acidophilus culture from 5.7 to $9.7 \log _{10}$ cfu/g. But addition of skim milk powder in the present study was $1 \%$. Harrigan (1998) replaced manganese sulphate with tomato juice indicating that tomato juice may be rich in manganese sulphate in Gibson semi solid medium.

The stimulatory ability of $\mathrm{MnSO}_{4}$ at $0.05 \%$ in MRS broth was observed with respect to the growth of BifidobacteriumlongumPF1 from 6 to $8.8 \log _{10} \mathrm{cfu} / \mathrm{g}$. Ash guard, carrot and tomato juice when incorporated into skim milk (18\% TS), inoculated with BifidobacteriumlongumPF1, took $18 \mathrm{~h}$ to curdle at $37^{\circ} \mathrm{C}$ compared to plain skim milk ( $48 \mathrm{~h}$ to curdle) indicating the prebiotic nature of natural vegetable juices (Prabha, 1999).

Ramachandra et al., (2008) reported that paddy husk lacking in the nutrients was incorporated with various supplements such as peptone (1\%) as nitrogen source, yeast extract $(1 \%)$ as vitamin source, skim milk powder $(1 \%)$ for adaptation to milk, $\mathrm{MnSO}_{4}$ $(0.05 \%)$ as mineral source, black gram dhal $(1 \%)$ as protein source, tween $40(1 \%)$ as 
surfactant that enhanced the growth of Lactobacillus acidophilus 111 at $37^{\circ} \mathrm{C}$ for 48 $\mathrm{h}$ from $6 \log$ to $10 \log _{10} \mathrm{cfu} / \mathrm{g}$ compared to non-supplemented paddy husk medium.

Dahi culture was grown on black gram dhal containing $70 \%$ moisture supplemented with $1 \%$ skim milk powder and $10 \%$ tomato juice at $30^{\circ} \mathrm{C}$ for $24 \mathrm{~h}$ where in DMC attained was $9.42 \log _{10}$ cell/g (Deepa, 2011).

Various dhals as solid substrates were used for growing biomass of lactic acid bacterial cultures after screening for bacterial spores. Among dhals tested, black gram dhal showed lowest spore count. Then black gram dhal treated with sporicidal treatment such as Hot air oven at $100^{\circ} \mathrm{C}$ for $1 \mathrm{~h}$ and sterilization at $121^{\circ} \mathrm{C}$ for $30 \mathrm{~min}$ completely destroyed the spores. In order to get maximum growth, black gram dhal was added with various supplements each of skim milk powder, ash guard juice, carrot juice and tomato juice as sources of growth factors or prebiotic for lactic and probiotic cultures at the rate of 0.5 , $1,1.5$ and $2 \%$. The optimum growth was obtained when supplements were added each at $1 \%$ concentration with maximum viable counts of dahi (8.41), yoghurt (8.98) and acidophilus (9.47 $\log 10 \mathrm{cfu} / \mathrm{g})$.

\section{References}

Bevilacqua, A., Sinigaglia, M.,Corbo, M.R., 2008. Alicyclobacillus acidoterrestris: New methods for inhibiting spore germination. Int. J. food Microbiol., 125: 103-110.

Bhargav, S., Panda, B.P., Ali, M., Javed, S., 2008. Solid-state Fermentation: An
Overview. Chem. Biochem. Eng., 22(1): 49-70.

Deepa, B.G., 2011. Production of Direct Vat Set dahi cultures. M.Tech thesis submitted to KVAFSU, Bidar, India.

Harrigan., 1998. Laboratory methods in food and dairy microbiology, Department of Food Science, Reading Univ., Reading Academy Press Inc. (London) Ltd. UK.

Koyani, R.D. and Rajput, K.S., 2015. Solid state fermentation: Comprehensive tool for utilization of lignocellulosic through biotechnology. Bioprocess. Biotech., 5(10): 1-15.

Nakauma, M., Saito, K., Katayama, T., Tada, M. and Todoriki, S., 2004. Radiation-heat synergism for inactivation of Alicyclobacillus acidoterrestris spores in citrus juice. J. food Protection., 67: 25382543.

Prabha, R., 1999. Production and incorporation of wild strains of Bifidobacteria in the baby foods. Ph.D. thesis submitted to UAS., Bengaluru.

Ramachandra, B., Manjunatha, H., Prabha, R., Krishna, R. and Shankar, P.A., 2008. Production and performance evaluation of of Bifidobacterium longum F8 in milk grown on solid state fermentation (SSF) medium. Ind. J. Dairy and Biosci., 19(12).

Somavat, R., Mohamed, H.M., Chung, Y.K., Yousef, A.E. and Sastry, S.K., 2012. Accelerated inactivation of Geobacillus stearothermophilus spores by ohmic heating. J. Food Eng., 108: 69-76.

Vanisri, D.S., 1995. Preparation of performance of dairy starter cultures using solid state fermentation. M.Sc. thesis submitted to UAS, Bengaluru.

\section{How to cite this article:}

Akshaykumar, H. Manjunatha and Ramachandra, B. 2017. Production of Biomass of Lactic Acid Bacteria Using Optimized Solid Substrate in Self-Technique. Int.J.Curr.Microbiol.App.Sci. 6(12): 2890-2898. doi: https://doi.org/10.20546/ijcmas.2017.612.336 